\title{
Spatial and temporal patterns of plant functional types under simulated fire regimes
}

\author{
Juli G. Pausas ${ }^{\mathrm{A}, \mathrm{C}}$ and F. Lloret ${ }^{\mathrm{B}}$

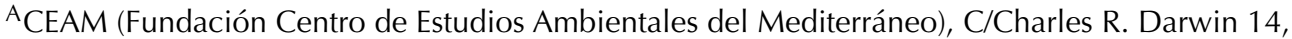 \\ Parc Tecnològic, 46980 Paterna, València, Spain \& Departament d'Ecologia, \\ Universitat d'Alacant, Apartat Correus 99, E-03080, Alacant, Spain. \\ ${ }^{B}$ CREAF (Center for Ecological Research and Forestry Applications) and Unit of Ecology, \\ Department of Animal and Plant Biology and Ecology, Autonomous University \\ of Barcelona, E-08193 Bellaterra, Barcelona, Spain. \\ CCorresponding author. Email: juli@ceam.es, pausas@gmail.com
}

\begin{abstract}
In spite of enormous fire suppression advances in Mediterranean countries, large high-intensity fires are still common. The effects on vegetation structure and composition of fire and fire regime changes at large spatial and temporal scales are poorly known, and landscape simulation models may throw some light in this regard. Thus, we studied how the abundance, richness, and spatial distribution of the different plant types are sensitive to the frequency, extent and spatial distribution of wildfires, using a landscape simulation model (FATELAND). We simulated the dynamics of 10 plant functional types (PFTs) defined as combinations of post-fire persistence strategies and life forms, under the following fire scenarios: No Fire, Suppressed (one large fire every 20 years), Prescribed (small fuel reductions every year), Unmanaged-1 (two small fires every year) and Unmanaged-2 (four small fires every year). The results suggest that the different fire regimes generate different spatial fire-recurrence patterns and changes in the proportion of the dominant species. For instance, with increasing fire recurrence, seeder shrubs (i.e. those recruiting new individuals after fire from persisting seed bank) with early reproduction increased and seeder trees decreased, while little variation was found for resprouters. Fire also increased the spatial aggregation of plants, while PFT richness decreased with increasing fire recurrence. The results suggest patterns of changes similar to those reported in field studies, and thus they provide consistent hypotheses on the possible vegetation changes due to different fire scenarios.
\end{abstract}

Additional keywords: FATE model, landscape model, Mediterranean, resprouter, seeder, simulation, vegetation dynamics.

\section{Introduction}

In spite of enhanced suppression efforts in most Mediterranean countries, high-intensity large fires are still common (Moreno et al. 1998; Keeley et al. 1999). In recent times, increasing climatic risks, fuel loads and ignition sources have created the complex network of interactions that promote this situation (Pausas 2004). The main management strategies are firefighting and fuel reduction; the latter may include prescribed fires and clear-cutting. These two strategies may lead to quite different fire regimes and contrasting burned-area spatial distributions (Minnich and Chou 1997). Efficient firefighting may preserve large unburned areas where fuel accumulates and promotes highintensity large fires that easily escape control. This strategy is commonly followed in countries of the Mediterranean basin. In contrast, the fuel reduction strategy aims to produce a landscape mosaic of fuel patches, thus limiting fire spread. According to this strategy, the difficulties of applying fuel control measures to large areas can be overcome by establishing selected sites as fire propagation barriers. However, the efficiency of this practice is determined by the repetition of prescribed burnings at relatively short intervals, generating patches of very high fire recurrence. Although high fire frequencies in areas that are repetitively burned can strongly affect plant composition and structure, prescribed burning remains a common practice in many Mediterranean landscapes (e.g. van Wilgen et al. 1992; Keeley 2006).

Community resilience is based on the demographic mechanisms that allow plant populations to recover after disturbances. When considering wildfires, the ability to resprout after fire and the ability to recruit from persistent seed banks are the two main mechanisms invoked to explain this response (Pausas et al. 2004). These regenerative attributes have been used to define plant functional types (PFTs) - species whose similar biologies (i.e. based on different life-history traits, such as life span, dispersal ability, recruitment requirements, and post-fire regenerative traits), result in a similar response to ecological constraints, such as disturbances (Lavorel et al. 1997; McIntyre et al. 1999; Pausas and Lavorel 2003), and fire regime in particular (Pausas 1999; Lloret and Vilà 2003; Pausas et al. 2004).

Many studies have described the patterns of post-fire plant regeneration in Mediterranean-type ecosystems and showed that the vegetation is generally resilient to disturbances, such as wildfires (Keeley 1986; Malanson and Trabaud 1987). However, the regeneration process may be sensitive to different fire 
regimes, depending on specific demographic characteristics and post-fire recovery strategies (Zedler et al. 1983; Pausas 1999). Thus, the increasing effort to investigate resilience thresholds at population and community level has addressed the role of individual characteristics, environmental constraints, and disturbance regime (Zedler et al. 1983; Zammit 1988; Rodrigo et al. 2004; Konstantinidis et al. 2006). In particular, the increase in fire frequency during the last decades in the Mediterranean basin (Piñol et al. 1998; Pausas 2004) has raised concern about the limits to resilience in plant communities of the region (Lavorel et al. 1998; Grove and Rackham 2001; Díaz-Delgado et al. 2002; Eugenio and Lloret 2004; Rodrigo et al. 2004; Broncano et al. 2005; Delitti et al. 2005).

Fire may be considered a source of spatial heterogeneity. It promotes the existence of a mosaic of burned areas with different sizes and fire histories, thus showing different stages of recovery (Turner 1989; Haydon et al. 2000). Nevertheless, within the areas burnt in high-intensity crown fires, fire may produce homogenisation (i.e. spatial similarity in the structure and composition of the vegetation) (Turner et al. 1994), at least during the early post-fire period, e.g. by promoting even-aged populations of seeder species. Although several attempts have been made to investigate the relationship between fire and landscape (e.g. Romme 1982; Baker 1994; Turner and Romme 1994; Haydon et al. 2000; Weir and Johnson 2000; Moreira et al. 2001; Lloret et al. 2002), few studies have addressed the impact of the disturbance regime on the spatial distribution of the biological units that constitute the community. For example, the spatial distribution of some species may reproduce the historical fire distribution. Species with post-fire persistence traits may be common in burned areas while sensitive species may be excluded (Zedler 1995a; Lloret et al. 2005). Therefore, the patterns of species richness and composition may differ between the regional scale, where fire generates a mosaic in which species with different fire tolerances may coexist, and the local scale, where the sequences of fire events (characterised by their recurrence and intervals) may determine particular species assemblies (Lloret and Vilà 2003; Schoennagel et al. 2004).

Several practical problems arise when investigating longterm vegetation dynamics in relation to disturbances, such as fire. First, long-term experiments under field conditions with reliable replication of fire regimes and controls are difficult to establish. Second, given the variation between different communities, it is difficult to quantitatively compare fire responses from field experiments. Simulation approaches allow us to consider sets of species at large spatial and temporal scales (Pausas 2003, 2006; Mladenoff 2004). Then we can build models that take into account the performance of coexisting plant types on the basis of their life history, including post-fire behaviour and competition ability, under different fire-regime spatial scenarios (Franklin et al. 2005; Grigulis et al. 2005; Pausas 2006; Syphard et al. 2006).

The main goal of this study is to investigate the effect of the fire regime, specifically fire recurrence, extent and spatial distribution, on plant communities consisting of several PFTs defined by life-history traits - representative of the vegetation from the Mediterranean basin. We are particularly interested in investigating how the abundance, richness, and spatial distribution of the different PFTs are sensitive to the recurrence, extent, and spatial distribution of wildfires across a given territory. We expect that different fire regimes should generate different spatial recurrence patterns, and these should have consequences on species composition and abundance at local scale, and on spatial pattern at landscape scale. Our approach considers different landscape management scenarios, mimicking the firefighting and fuel-reduction strategies that result in contrasting fire-regime patterns. We consider two scales: the landscape scale, constituted by a mosaic of burned patches, and the local scale, constituted by areas with the same fire recurrence.

\section{Methods}

\section{Functional types}

Ten PFTs occurring in the Eastern Iberian Peninsula (western Mediterranean basin) were characterised (Table 1) in order to model their dynamics. In this region, the vegetation is dominated by sclerophyllous, evergreen shrublands, and forests, although some patches of grassland, associated mainly with abandoned old-fields, can also be found (Bonet and Pausas 2004). In the last decades, the number and extent of forest fires have increased, in spite of active management based on fire suppression and fuel reduction by clipping (Díaz-Delgado et al. 2004a; Pausas 2004). Most of these fires have an anthropogenic origin. For example, in Catalonia (ca. $31900 \mathrm{~km}^{2}$ ), located in the northern part of the study area, the burned forestland was $\sim 12 \%$ in the $1975-1998$ period, and the estimated mean fire return interval in landscape units of $8 \mathrm{~km}^{2}$ was 5.5 years (Díaz-Delgado et al. 2004b). Further south, in the province of Valencia, the burned forestland was $\sim 45 \%$ in the $1978-2001$ period, and the fire return interval ranged from 2 to 22 years in the different patches; $\sim 11 \%$ of the forestland suffered recurrent fires with fire intervals shorter than 15 years (Pausas 2004; Pausas and Abdel Malak 2004).

The traits of the selected PFTs mimic the syndromes of representative species in the region. Although the values given for some parameters do not correspond to direct field estimations, they provide a reliable description of plant types according to field observations from the authors and from the literature (Papió 1994; Lloret 1998; Pausas et al. 1999; Lloret et al. 2003; Pausas and Verdú 2005). These PFTs include different life forms (trees, shrubs, perennial herbs, geophytes) with contrasted regenerative strategies. The regeneration strategies were defined by the combinations of two binary traits, resprouting ability (R) and seed-persistence ability (S) (Pausas et al. 2004): obligate resprouters $(\mathrm{R}+\mathrm{S}-)$, obligate seeders $(\mathrm{R}-\mathrm{S}+)$, facultative species $(\mathrm{R}+\mathrm{S}+)$, and species without any post-fire persistence mechanism $(\mathrm{R}-\mathrm{S}-)$. Only the combinations of life forms and regenerative strategies found to be relevant in the study area were considered.

\section{The model}

To simulate the vegetation dynamic we used the FATELAND model (Pausas 2006; Pausas and Ramos 2006), which is a (gridcell) raster-based version of the FATE model (Moore and Noble 1990). This spatial version of FATE is included in the LASS modelling environment (Pausas and Ramos 2006, available at www.ceam.es/pausas/lass.htm). FATELAND (like FATE) runs at annual time steps and simulates cohorts of plants that pass through a series of four discrete stages: propagules, seedlings, 
Table 1. Life history traits of the simulated plant functional types (PFTs)

\begin{tabular}{|c|c|c|c|c|c|c|}
\hline Plant functional type & Example & First reproduction & Lifespan (years) & Resprouting & Seeds killed by fire & Fecundity \\
\hline Tree, resprouter $(\mathrm{T} \mathrm{R}+\mathrm{S}-)$ & Quercus & 20 & 200 & High & Very high & Low \\
\hline Tree, seeder $(\mathrm{T} \mathrm{R}-\mathrm{S}+)$ & Pinus & 15 & 120 & No & Low & High \\
\hline Shrub, resprouter ( $\mathrm{R}+\mathrm{S}-$ ) & Erica & 7 & 40 & High & High & Medium \\
\hline Shrub, seeder $(\mathrm{S} R-\mathrm{S}+)$ & Cistus & 3 & 15 & No & Very low & High \\
\hline Shrub, resprouter-seeder $(\mathrm{S} R+\mathrm{S}+)$ & Dorycnium & 5 & 25 & Medium & Low & High \\
\hline Shrub, fire-sensitive (S R-S-) & Juniperus & 10 & 70 & No & Very high & Low \\
\hline Perennial herb, resprouter $(\mathrm{H} \mathrm{R}+\mathrm{S}-)$ & Brachypodium & 4 & 20 & High & High & Low \\
\hline Perennial herb, seeder (H R-S+) & Sanguisorba & 2 & 5 & No & Medium & Medium \\
\hline Geophyte (G R+S-) & Iris & 1 & 5 & High & High & Low \\
\hline Annual herb (Annual) & Anagallis & 1 & 2 & No & Very high & High \\
\hline Plant functional type & $\begin{array}{l}\text { Seed } \\
\text { dispersal }\end{array}$ & $\begin{array}{l}\text { Innate seed } \\
\text { dormancy }\end{array}$ & $\begin{array}{l}\text { Fire stimulated } \\
\text { seed bank }\end{array}$ & $\begin{array}{l}\text { Shade } \\
\text { germination }\end{array}$ & $\begin{array}{l}\text { Shade } \\
\text { survival }\end{array}$ & Fuel \\
\hline Tree, resprouter (T R+S-) & Low & No & No & Medium & High & Medium \\
\hline Tree, seeder (T R-S+) & High & No & Yes & Very low & Low & High \\
\hline Shrub, resprouter (S R+S-) & Medium & Low & No & Medium & Medium & High \\
\hline Shrub, seeder $(\mathrm{S} R-\mathrm{S}+)$ & Medium & High & Yes & Very low & Low & High \\
\hline Shrub, resprouter-seeder $(\mathrm{S} R+\mathrm{S}+)$ & Medium & Medium & Yes & Low & Low & High \\
\hline Shrub, fire-sensitive (S R-S-) & Low & Low & No & Low & Medium & Medium \\
\hline Perennial herb, resprouter $(\mathrm{H} \mathrm{R}+\mathrm{S}-)$ & Low & No & No & Very low & High & Medium \\
\hline Perennial herb, seeder (H R-S+) & Low & Low & Yes & Low & High & Medium \\
\hline Geophyte (G R+S-) & Medium & No & No & Very low & Medium & Low \\
\hline Annual herb (Annual) & Medium & Medium & No & Very low & Medium & Low \\
\hline
\end{tabular}

Table 2. Simulated fire regime scenarios. Prescribed scenario includes areas submitted to regular prescribed burnings and areas where fires occurred randomly (see main text)

\begin{tabular}{lccccr}
\hline Scenarios & \# Fire years & $\begin{array}{c}\text { Fire interval at } \\
\text { landscape scale }\end{array}$ & $\begin{array}{c}\text { Annual area burnt } \\
(\% \text { of the landscape })\end{array}$ & Spatial pattern & $\begin{array}{c}\text { Cumulative area } \\
\text { burnt }(\%)\end{array}$ \\
\hline No Fire & 0 & - & - & - & 0 \\
Suppressed & 5 & 20 & 50 & Random & 250 \\
Prescribed & 100 & 1 & 2.5 & Systematic + random & 250 \\
Unmanaged-1 & 100 & 1 & 2.5 & Random & 250 \\
Unmanaged-2 & 100 & 1 & 5 & Random & 500 \\
\hline
\end{tabular}

immature, and mature plants. Input values (Table 1) include both quantitative and qualitative ones. Dispersal to any cell is possible; the probability of dispersal follows a negative exponential equation, with parameters depending on the seed dispersal trait (see Table 1). The model includes three levels of light availability (low, medium, and high) determined by the vertical structure of the vegetation (stratum). Germination and survival are determined on the basis of these light availability levels, and changes in light availability are due to species overtopping each other (competition). The abundance of each plant life stage at cell level is simulated in a qualitative manner (absent, low, medium, and high abundance), for the different species (in our case PFTs) that coexist in a given cell. These abundance categories are estimated for each species and are not related to the abundance of the remaining species. The core of the model (i.e. the FATE model) is deterministic, although FATELAND includes some stochasticity in the dispersal and fire modules (Pausas 2006). Because previous runs showed very little variability between runs (Pausas 2006), replications have not been considered here. Full details on this model can be found in Moore and Noble (1990) and Pausas (2006).

\section{Simulation scenarios}

We generated a landscape of $200 \times 200$ cells of 1 ha each (40 000 ha). Each PFT was randomly distributed in 50\% of the cells; thus, the number of PFTs in each cell range from 0 (empty cells) to 10 (all PFTs). The qualitative abundance of each PFT in each cell was set to medium.

Five disturbance scenarios (named: No Fire, Suppressed, Prescribed, Unmanaged-1, and Unmanaged-2) were applied for 100 years (Table 2), and then an additional 5-year period without any fire was run before sampling to avoid the immediate effects of the last disturbances. The disturbance scenarios mimic the different situations of fire occurrence in the region, related to fire suppression and fuel control policies, as well as a control (No Fire) scenario. The Suppressed scenario was simulated by setting a fire that affected $50 \%$ of the landscape every 20 years. 
This situation mimics the suppression policy that results in few large fires. In the Suppressed, Unmanaged-1, and Unmanaged-2 scenarios, fire was initiated in a randomly chosen non-empty cell and spread freely without any burning-out procedure. In the Prescribed fire, the cells were systematically chosen. Fire spread was based on the amount of fuel in each cell, and thus the shape of the area burned was also based on the fuel distribution. The fuel in the cell is computed on the basis of the species abundance in the cell and their flammability (defined as low, medium, or high). The higher the fuel and/or flammability, the higher the probability of the cell being burned. Thus, the fire module is very simple and, unlike most mechanistic fire-simulation models, does not intend to be very realistic in the sense of predicting fire size or area burnt. On the contrary, the objective of this module was to be able to impact on the landscape, produce plant mortality and generate opportunities for post-fire regeneration, thus generating dynamics processes.

The prescribed scenario was simulated by systematically burning every year 12 areas of $6 \times 6$ cells, i.e. $1.08 \%$ of the landscape. These 12 burned patches were evenly spaced between the two opposite sides of the landscape, and each year the burns were displaced; every 10 years the same 12 areas were re-burned. Together with these systematic burns, the prescribed scenario also includes two small random annual fires that burned $1.42 \%$ of the landscape (wildfires). The Unmanaged-1 scenario was simulated by randomly setting two fires every year, which burned a total of $2.5 \%$ of the landscape each year, resulting in many small fires throughout the whole 100-year period. An additional scenario (Unmanaged-2) was added to simulate a scenario similar to the Unmanaged-1 but with twice the area affected by fire, that is, four fires occurred every year, burning a maximum of $5 \%$ of the landscape.

These unmanaged scenarios mimic the situation expected when non-suppressed frequent fires generate a landscape mosaic of fuel patches resulting in small-to-medium-size burned areas (Minnich and Chou 1997). Recent modelling exercises for the study region indicated that the different fire-management strategies do not result in striking differences in the total burned area in the long-term, but rather in contrasting fire-size distribution patterns, with the larger fires under a fire suppression strategy (Piñol et al. 2005). Note that in our case the Suppressed, Prescribed, and Unmanaged-1 scenarios burned the same amount of landscape by the end of the simulation, while the Unmanaged-2 scenario burned double that amount (Table 2).

The simulation results were analysed using the tools included in the LASS shell (Pausas and Ramos 2006). Spatial analysis of fire recurrences and species abundance was computed using the Moran's I autocorrelation index. This index ranges from -1 to 1; high values indicate spatial autocorrelation (aggregation), values close to 0 indicate even distribution, and values close to -1 indicate segregation (repulsion).

\section{Results}

After 105 years of simulations, the four fire scenarios generate different landscape mosaics in which the area burned with different recurrences shows distinct patterns (Figs 1 and 2). Mean fire recurrence for the whole simulated period is 2.5 fires/cell for the Suppressed (s.d. = 1.4) and Unmanaged-1 (s.d. = 1.6) scenarios,
2.9 (s.d. = 3.7) fires/cell for the Prescribed and 5 (s.d. = 2.1) fires/cell for the Unmanaged-2 scenario, with the range of this parameter being widest in the Prescribed scenario (Fig. 2). If we exclude the patches where the prescription fires were repeatedly performed, mean fire recurrence in the Prescribed scenario was 1.44 fires/cell. In all the scenarios, fire recurrences show a significant $(P<0.0001)$ spatial autocorrelation; this is highest in the Suppressed $(I=0.929)$ and lowest in the Prescribed $(I=0.770)$ scenarios, and intermediate in the Unmanaged-1 $(\mathrm{I}=0.870)$ and Unmanaged-2 $(\mathrm{I}=0.848)$ scenarios.

With the exception of the geophytes (Fig. 3), most of the PFTs occur in a large portion of the landscape in all scenarios. This is a consequence of the relatively large size of the cells (1 ha) and the ability of most species to coexist at this scale. Therefore, few changes in the proportion of landscape occupied are observed in relation to fire regime, except for the fire-sensitive type ( $\mathrm{S} \mathrm{R}-\mathrm{S}-$ ). Nevertheless, some relevant changes are observed when considering dominant PFTs, i.e. the PFT with mature individuals and with medium or high abundance (shaded pattern in Fig. 3). Comparisons with the No Fire scenario indicate that fire tends to increase $\mathrm{R}-\mathrm{S}+$ and $\mathrm{R}+\mathrm{S}+$ shrubs, particularly in the Suppressed scenario for $\mathrm{R}-\mathrm{S}+$. The opposite is found for $\mathrm{R}-\mathrm{S}+$ trees. The resprouter types exhibit small decreases with fire. Plant-type abundance pattern differences between the Suppressed, Prescribed, and Unmanaged-1 scenarios are small. The increase in burned surface (i.e. comparing Unmanaged-1 with Unmanaged-2) produces a slight decrease in the occurrence of $\mathrm{R}-\mathrm{S}+$ and $\mathrm{R}+\mathrm{S}+$ shrubs and a reduction in the abundance of $\mathrm{R}+\mathrm{S}-$ shrubs. Trees seem to be less sensitive to these changes. Short-lived species (perennial herbs, geophytes, annuals), particularly geophytes, show lower abundance values than shrubs and trees.

Fires, however, produce contrasting patterns of PFT spatial distribution, as estimated by the Moran autocorrelation index (Fig. 4). First, fire occurrence increases the degree of aggregation of most plant types, except geophytes. Accordingly, the Unmanaged-2 simulation, with more accumulated burned area, produces a more aggregated pattern in most PFTs than the Unmanaged-1 simulation, except in fire sensitive types. Aggregation was higher in Prescribed than in Suppressed, Unmanaged-1 and Unmanaged-2 scenarios for R-S+ trees and $\mathrm{R}+\mathrm{S}+$ shrubs. For most PFTs, the lowest aggregation was found for Unmanaged-1 and Unmanaged-2 scenarios.

Fire reduces the PFT richness at landscape scale (Fig. 5). The extent of the cells allows the coexistence of most plant types and the mean richness value per cell is high ranging, from 8.19 (s.d. $=0.97$ ) in the No Fire scenario to 6.84 (s.d. $=1.20$ ) in the Unmanaged-2 one. The other three scenarios show similar, intermediate values $(7.44 \pm 1.28$ for Prescribed, $7.24 \pm 1.24$ for Suppressed, and $7.41 \pm 1.24$ for Unmanaged-1).

Fire recurrence at cell level also reduces PFT richness in all scenarios (Fig. 6), with the steepest decrease found in the Suppressed scenario. The areas repeatedly burned (10 or more times) in the Prescribed scenario show the lowest richness values. Similar values are also reached in the Unmanaged-2 scenario at high recurrence levels.

Fire also modifies the spatial clustering of PFT richness. While richness is evenly distributed in the No Fire scenario $(I=0.005)$, the Suppressed scenario shows the highest 
Suppressed

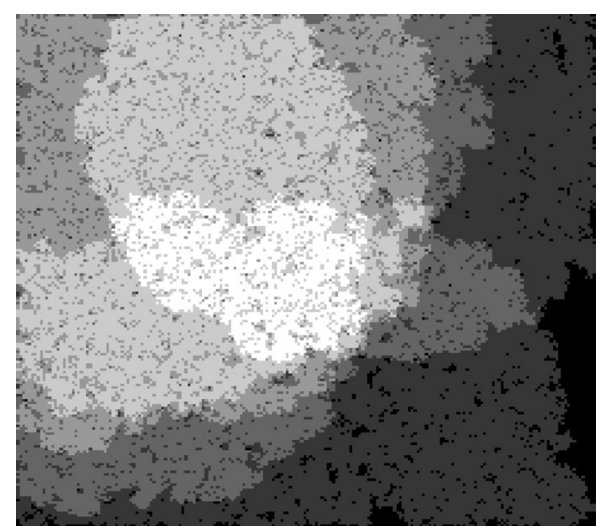

Unmanaged-1

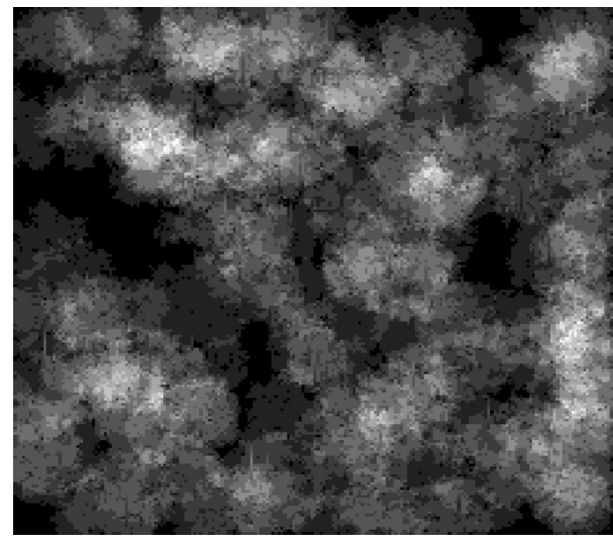

Prescribed

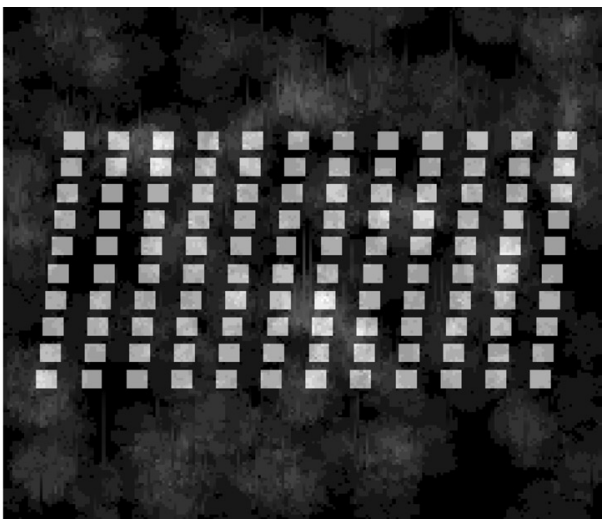

Unmanaged-2

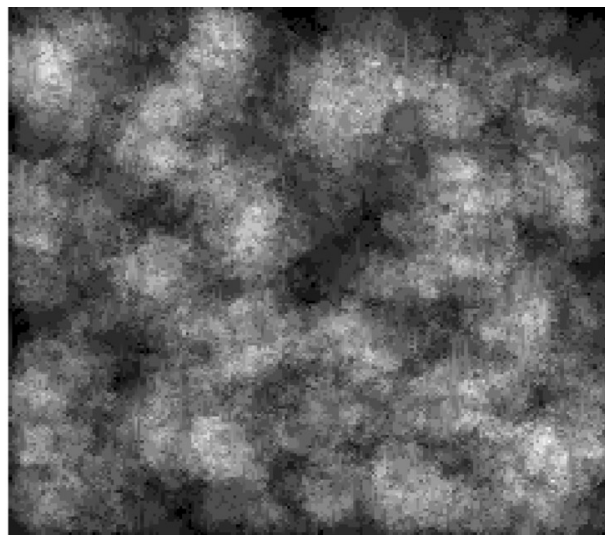

Fig. 1. Fire recurrence maps for the four simulated scenarios $(200 \times 200$ cells $)$ after 100 years of simulation. The grey scale goes from black for the lowest fire recurrence to white for the highest fire recurrence in each scenario.

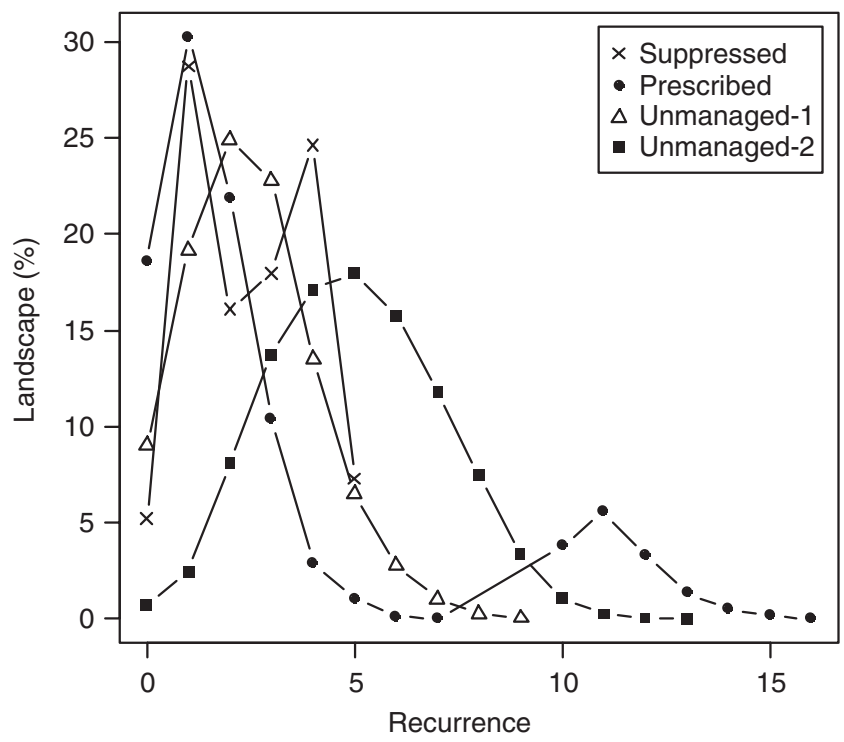

Fig. 2. Fire recurrence (number of fires in 100 years) pattern under the different fire regime scenarios, estimated as the percentage of the landscape (cells) where a given number of fires occurred. autocorrelation values $(I=0.240)$, followed by the Prescribed scenario $(I=0.182)$. Unmanaged simulations produce lower values $(I=0.139$ for Unmanaged-1; $I=0.106$ for Unmanaged-2).

\section{Discussion}

Our fire scenarios produce different fire recurrence patterns and landscape structures. As expected, the scenario with the highest cumulative area burned produces the highest proportion of landscape with high recurrences. Among the other scenarios, the Prescribed one produces the lowest levels of mean recurrence in the areas that were not exposed to the prescribed fires.

Fire occurrence produces relevant changes in the abundance patterns of some PFTs. Thus, among shrubs fire tends to increase the abundance of the seeder strategy, as found in the increased abundance of $\mathrm{R}-\mathrm{S}+$ and $\mathrm{R}+\mathrm{S}+$ shrubs when compared with the No Fire scenario. Several studies have empirically found similar patterns at stand and regional level (Franklin et al. 2004; Pausas et al. 2004; Lloret et al. 2005). This was explained by fire-stimulated germination and the advantages of establishing new recruits just after fire, when resource availability is high and competition diminishes. However, when increasing fire frequency is modelled in the Unmanaged-2 scenario, it results in a 


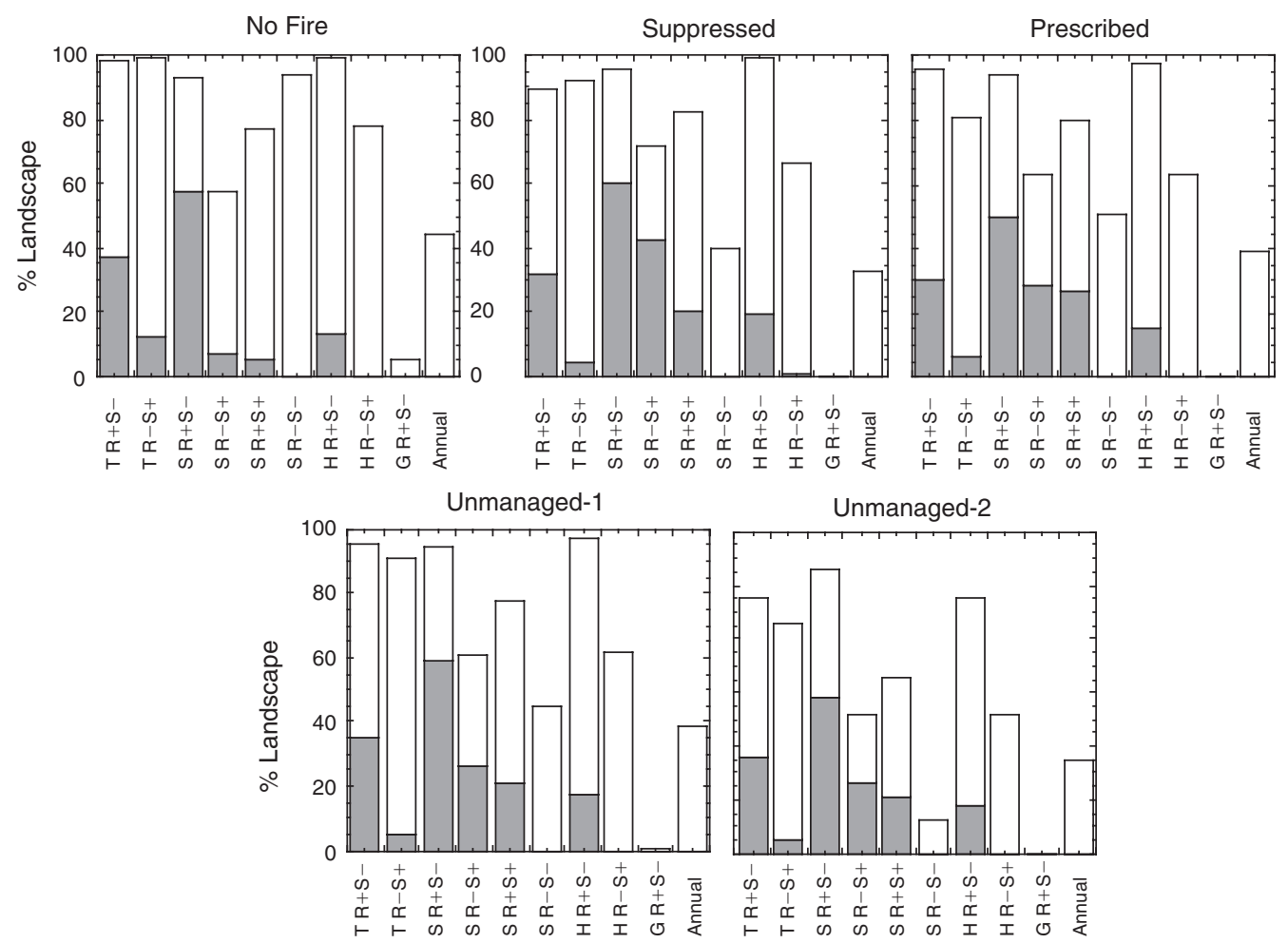

Fig. 3. Percentage of the landscape (cells) occupied by the different plant functional types (PFTs) after 105 years (100 years of fire regime plus 5 years without fire) of FATELAND simulations under the different fire regime scenarios. The dark section of the bars indicates the percentage of cells showing medium or high abundance while the light section of the bars indicates the proportion of cells with low abundance. T R+S-: Tree, Resprouter; T R-S+: Tree, Seeder; S R+S-: Shrub, Resprouter; S R-S+: Shrub, Seeder; S R+S+: Shrub, Facultative species; S R-S-: Shrub, Fire-sensitive; H R+S-: Perennial herb, Resprouter; H R-S+: Perennial herb, Seeder; G R+S-: Geophyte, Resprouter; Annual: Annual herb.

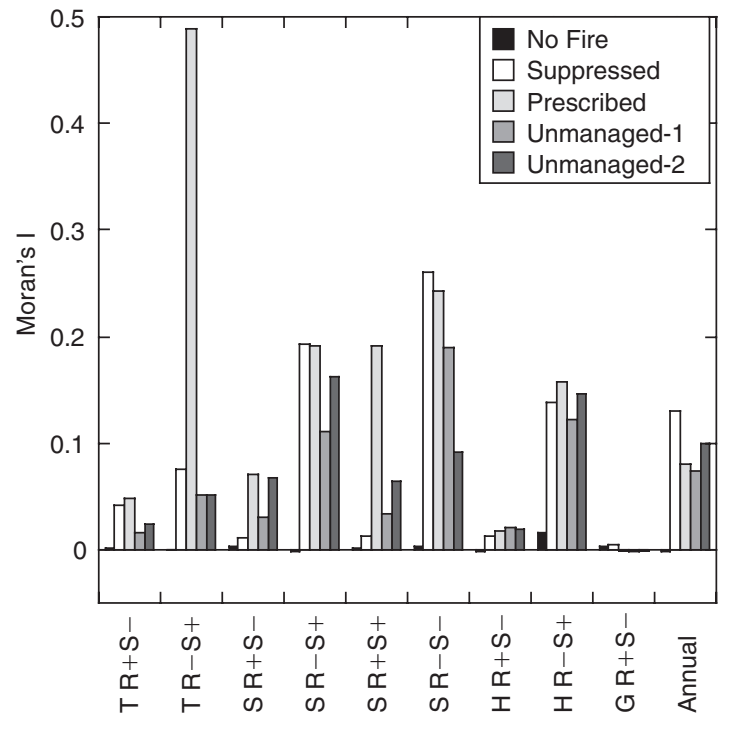

Fig. 4. Spatial aggregation pattern of the different plant functional types (PFTs) under the different fire regime scenarios computed using Moran's I index. T R+S-: Tree, Resprouter; T R-S+: Tree, Seeder; S R+S-: Shrub, Resprouter; S R-S+: Shrub, Seeder; S R+S+: Shrub, Facultative species; S R-S-: Shrub, Fire-sensitive; H R $+\mathrm{S}-$ : Perennial herb, Resprouter; H R-S+: Perennial herb, Seeder; G R+S-: Geophyte, Resprouter; Annual: Annual herb. tendency to decrease the occurrence of these species, suggesting that they are favoured either at intermediate fire levels or by the spatial pattern of their fire history (i.e. by a continuous area of high fire recurrence). In the case of tree seeders (e.g. Pinus halepensis), their abundance tends to decrease with fires, probably because fire intervals that are too short do not allow recruiting cohorts to mature, even though habitat heterogeneity may facilitate their persistence (Pausas 2003, 2006). The recruitment limitation based on short fire intervals is well known for seeder trees and shrubs living in the Mediterranean Basin and California (Keeley et al. 1999; Lloret et al. 2003; Jacobson et al. 2004; Marcia et al. 2006; Syphard et al. 2006). Resprouting species are less sensitive to fire regimes, as reported by many field studies (Malanson and Trabaud 1987; Pausas et al. 2004; Delitti et al. 2005; Lloret et al. 2005). The changes in PFT abundance were small when fire regimes with the same accumulated burned area were compared; this indicates that the spatial distribution of fires plays a small role in PFT abundance at the overall landscape level.

At cell scale, many PFTs were able to coexist, a common pattern in many Mediterranean communities (Le Maitre and Midgley 1992; Zedler 1995b; Ojeda et al. 1996). The cell size (ca $1 \mathrm{ha}$ ) would be too large to detect the effect of competitive interactions. In addition, Huston (1994) proposed the combination of relatively low productivity and a moderate disturbance regime to explain the coexistence of many species in Mediterranean 


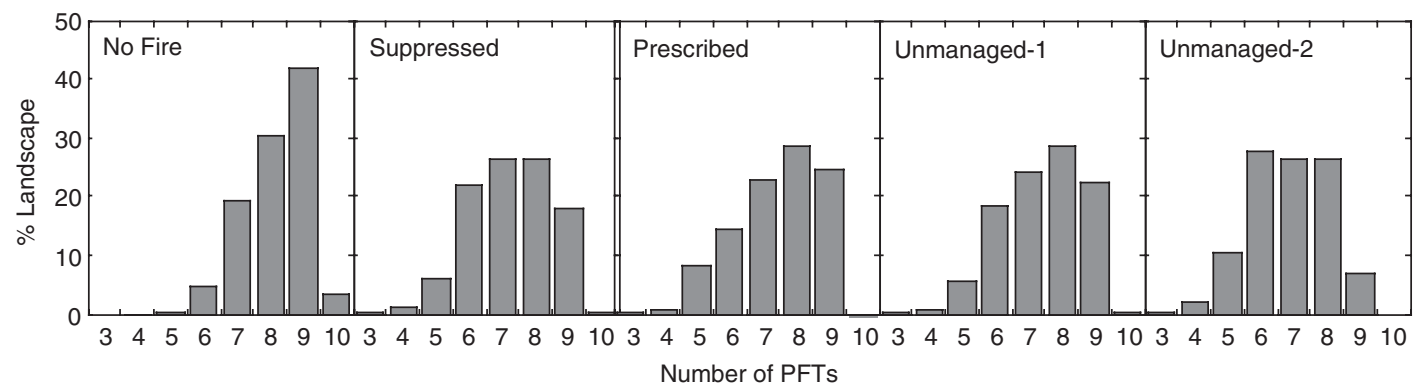

Fig. 5. Class distribution of richness of plant functional types (PFTs) under the different fire regime scenarios, estimated as the percentage of the landscape (cells) where a given number of plant types were present.

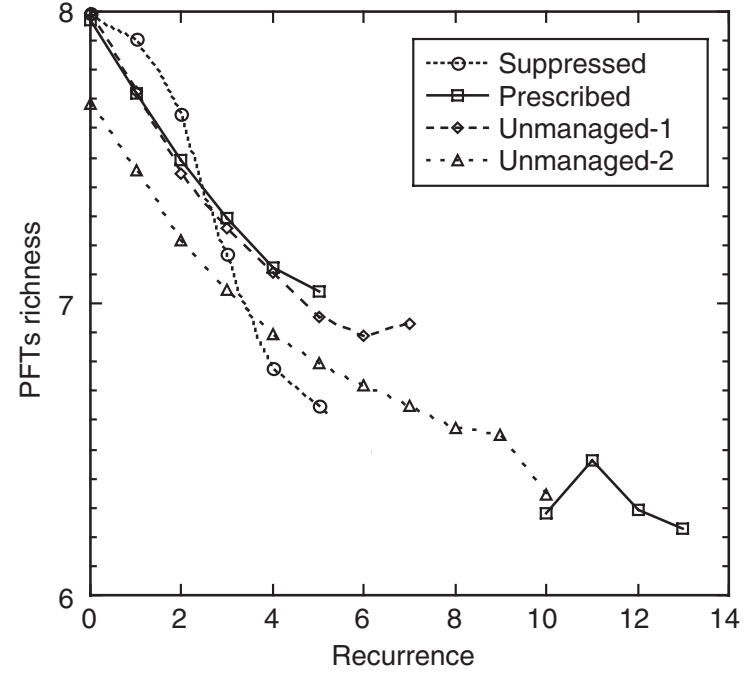

Fig. 6. Relationship between fire recurrence (number of fires in 100 years) and mean richness of plant functional types (PFTs) at cell scale (1 ha) under the different fire regime scenarios. Values for recurrence classes occurring in less than $1 \%$ of the landscape are not considered.

communities. The variety of post-disturbance mechanisms able to cope with a wide range of fire regimes, combined with the ability to use different resources, expressed as different growth types, is also likely to explain the high diversity records found in these ecosystems.

Overall, the richness in PFTs tends to decrease with fire occurrence at both landscape and local scale, as reported from field observations (Lloret and Vilà 2003). At landscape level, this is clear when comparing unburned scenarios with scenarios of increasing total burned area. The small differences in mean richness per cell between Prescribed, Suppressed and Unmanaged-1 scenarios suggest that at this large scale the recurrence and the spatial distribution of fires do not strongly modify PFT diversity. In contrast, at local scale there is a clear decrease in PFT richness with increasing fire recurrence. Obviously, this can be attributed mainly to fire-sensitive species (Riera and Castell 1997; Lloret and Vilà 2003; Pausas et al. 2004), although short-lived small types (geophytes, perennial resprouter herbs) with limited ability to disperse across the landscape are also likely to disappear.
Although fire may produce homogenisation after a single fire within the burned area at landscape (Turner et al. 1994) and community level (Pérez and Moreno 1998), in the long-term, fire clearly increases both the aggregation pattern of the different PFTs and the diversity of the whole set of PFTs. This may be caused by the adjustment of the plant population dynamics to the fire occurrence. The spatial distribution of PFTs with mechanisms allowing post-fire regeneration will reproduce the fire distribution patterns. Alternatively, PFTs lacking these regeneration mechanisms will avoid burned areas. This is the case of fire-sensitive species that exhibit a high aggregation pattern in the Suppressed scenario, in which small patches of unburned vegetation are expected to occur. In the Unmanaged-2 simulation, unburned areas were probably too scarce to produce a clear clumping pattern. In seeder trees, the increase in the autocorrelation index in the Prescribed scenario would be due to the exclusion of this type in recurrently prescribed burned areas.

\section{Conclusions}

The present modelling has provided us with insights into the effects of wildfire frequency, extent and spatial distribution on the abundance, richness, and spatial distribution of the different PFTs at large spatial and temporal scales. Although long-term field data are unavailable to validate some of our findings, the available field-based information (Riera and Castell 1997; Pausas et al. 1999; Lloret et al. 2002, 2005; Lloret and Vilà 2003; Franklin et al. 2004; Rodrigo et al. 2004) suggests similar patterns to those found in our simulation exercise. Thus, the results can be regarded as good working hypotheses to be fully validated as more information becomes available.

At landscape scale, our study suggests that for a given time period, the total burned area seems to be more relevant for the abundance and diversity patterns of PFTs than the temporal and spatial distribution of the fires. However, the spatial distribution patterns of these PFTs tend to reflect the past fire regime. At a local scale, fire recurrence promotes a limited loss of PFTs, favouring some regeneration modes that may take advantage of the post-fire conditions. In spite of the relevance of the spatial and temporal properties of fire regimes, many different PFTs are able to coexist at landscape and local scales where populations are able to avoid competitive exclusion. 


\section{Acknowledgements}

This work has been financed by the Spanish government's SINREG project (REN2003-07198-C02-01 and 02/GLO). It also contributes to the European research group (GDRE) project 'Mediterranean and mountain ecosystems in a changing world', funded by Generalitat de Catalunya and CNRS. CEAM is supported by the Generalitat Valenciana and Bancaixa.

\section{References}

Baker WL (1994) Restoration of landscape structure altered by fire suppression. Conservation Biology 8, 763-769. doi:10.1046/J.15231739.1994.08030763.X

Bonet A, Pausas JG (2004) Species richness and cover along a 60-year chronosequence in old-fields of southeastern Spain. Plant Ecology 174 257-270. doi:10.1023/B:VEGE.0000049106.96330.9C

Broncano MJ, Retana J, Rodrigo A (2005) Predicting the recovery of Pinus halepensis and Quercus ilex forests after a large wildfire in northeastern Spain. Plant Ecology 180, 47-56. doi:10.1007/S11258-005-0974-Z

Delitti W, Ferran A, Trabaud L, Vallejo VR (2005) Effects of fire recurrence in Quercus coccifera L. shrublands of the Valence Region (Spain). I. Plant composition and productivity. Plant Ecology 177, 57-70. doi:10.1007/S11258-005-2140-Z

Díaz-Delgado R, Lloret F, Pons X, Terradas J (2002) Satellite evidence of decreasing resilience in Mediterranean plant communities after recurrent wildfires. Ecology 83, 2293-2303.

Díaz-Delgado R, Lloret F, Pons FX (2004a) Spatial patterns of fire occurrence in Catalonia (NE Spain, 1975-1998). Landscape Ecology 19, 731-745. doi:10.1007/S10980-005-0183-1

Díaz-Delgado R, Lloret F, Pons X (2004b) Statistical analysis of fire frequency models for Catalonia (NE Spain) based on fire scar maps from Landsat MSS data. International Journal of Wildland Fire 13, 89-99. doi:10.1071/WF02051

Eugenio M, Lloret F (2004) Fire recurrence effects on the structure and composition of Mediterranean Pinus halepensis communities in Catalonia (northeast Iberian Peninsula). Ecoscience 11, 446- 454.

Franklin J, Sephard AD, He HS, Mladenoff DJ (2005) Altered fire regimes affect landscape patterns of plant succession in the foothills and mountains of southern California. Ecosystems 8, 885-898. doi:10.1007/S10021-005-0017-6

Franklin J, Coulter C, Rey SJ (2004) Change over 70 years in a southern California chaparral community related to fire history. Journal of Vegetation Science 15, 701-710. doi:10.1658/11009233(2004)015[0701:COYIAS]2.0.CO;2

Grigulis K, Lavorel S, Davies ID, Dossantos A, Lloret F, Vilà M (2005) Landscape-scale positive feedbacks between fire and expansion of the large tussock grass Ampelodesmos mauritanica in Catalan shrublands. Global Change Biology 11, 1042-1053. doi:10.1111/J.13652486.2005.00980.X

Grove AT, Rackham O (2001) The nature of Mediterranean Europe: an ecological history. (Yale University Press: New Haven, CT)

Haydon DT, Friar JK, Pianka ER (2000) Fire-driven dynamic mosaic in the Great Victoria Desert, Australia. 1. Fire geometry. Landscape Ecology 15, 373-381. doi:10.1023/A:1008138029197

Huston MA (1994) Biological Diversity: The Coexistence of Species on Changing Landscapes. (Cambridge University Press: Cambridge)

Jacobson AL, Davis SD, Babritius SL (2004) Fire frequency impacts nonsprouting chaparral shrubs in the Santa Monica Mountains of southern California. In 'Ecology, conservation and management of Mediterranean climate ecosystems'. (CD-ROM) (Eds M Arianoutsou, VP Panastasis) (Millpress: Rotterdam, Netherlands)

Keeley JE (1986) Resilience of Mediterranean shrub communities to fires In 'Resilience in Mediterranean-type ecosystems'. (Eds B Dell, AJM Hopkins, BB Lamont) pp. 95-112. (Dr. W. Junk Publisher: Dordrecht, Netherlands)
Keeley J (2006) Fire Management Impacts on Invasive Plants in the Western United States. Conservation Biology 20, 375-384. doi:10.1111/J.15231739.2006.00339.X

Keeley JE, Fotheringham CJ, Morais M (1999) Reexamining fire suppression impacts on brushland fire regimes. Science 284, 1829-1832. doi:10.1126/SCIENCE.284.5421.1829

Konstantinidis P, Tsiourlis G, Xofis P (2006) Effect of fire season, aspect and pre-fire plant size on the growth of Arbutus unedo L. (strawberry tree) resprouts. Forest Ecology and Management 225, 359-367. doi:10.1016/J.FORECO.2006.01.011

Lavorel S, McIntyre S, Landsberg J, Forbes TDA (1997) Plant functional classifications: from general groups to specific groups based on response to disturbance. Trends in Ecology \& Evolution 12, 474-478. doi:10.1016/S0169-5347(97)01219-6

Lavorel S, Canadell J, Rambal S, Terradas J (1998) Mediterranean terrestrial ecosystems: research priorities on global change effects. Global Ecology and Biogeography Letters 7, 157-166. doi:10.1046/J.1466822X.1998.00277.X

Le Maitre DC, Midgley JJ (1992) Plant reproductive ecology. In 'The ecology of Fynboss: nutrients, fire and diversity'. (Ed. RM Cowling) pp. 135-174 (Oxford University Press: Oxford)

Lloret F (1998) Fire, canopy and seedling dynamics in Mediterranean shrublands of Northeastern Spain. Journal of Vegetation Science 9, 417-430. doi: $10.2307 / 3237106$

Lloret F, Vilà M (2003) Diversity patterns of plant functional types in relation to fire regime and previous land use in Mediterranean woodlands. Journal of Vegetation Science 14, 387-398. doi:10.1658/11009233(2003)014[0387:DPOPFT]2.0.CO;2

Lloret F, Calvo E, Pons X, Díaz-Delgado R (2002) Wildfires and landscape patterns in the Eastern Iberian Peninsula. Landscape Ecology 17, 745 759. doi:10.1023/A:1022966930861

Lloret F, Pausas JG, Vilà M (2003) Response of Mediterranean plant species to different fire regimes in Garraf Natural Park (Catalonia, Spain): field observations and modelling predictions. Plant Ecology 167, 223-235. doi:10.1023/A:1023911031155

Lloret F, Estevan H, Vayreda J, Terradas J (2005) Fire regenerative syndromes of forest woody species across fire and climatic gradients. Oecologia 146 461-468. doi:10.1007/S00442-005-0206-1

Malanson GP, Trabaud L (1987) Ordination analysis of components of resilience of Quercus coccifera garrigue. Ecology 68, 463-472. doi: $10.2307 / 1938451$

Marcia E, Verkaia I, Lloret F, Espelta JM (2006) Density and growth decline in Pinus halepensis populations after recurrent wildfires in Catalonia (NE Iberian Peninsula). Forest Ecology and Management 231, 47-54. doi:10.1016/J.FORECO.2006.05.007

Mladenoff DJ (2004) LANDros. Inf. Serv. and forest landscape models. Ecological Modelling 180, 7-19. doi:10.1016/J.ECOLMODEL.2004. 03.016

McIntyre S, Lavorel S, Landsberg J, Forbes TDA (1999) Disturbance response in vegetation - towards a global perspective on functional traits. Journal of Vegetation Science 10, 621-630. doi:10.2307/3237077

Minnich RA, Chou YH (1997) Wildland fire patch dynamics in the chaparral of southern California and northern Baja California. International Journal of Wildland Fire 7, 221-248. doi:10.1071/WF9970221

Moore AD, Noble IR (1990) An individualistic model of vegetation stand dynamics. Journal of Environmental Management 31, 61-81. doi:10.1016/S0301-4797(05)80015-5

Moreira F, Rego FC, Ferreira PG (2001) Temporal (1958-1995) pattern of change in a cultural landscape of northwestern Portugal: implications for fire occurrence. Landscape Ecology 16, 557-567. doi:10.1023/A:1013130528470

Moreno JM, Vázquez A, Vélez R (1998) Recent history of forest fires in Spain. In 'Large Forest Fires'. (Ed. JM Moreno) pp. 159-185. (Backhuys Publishers: Leiden, The Netherlands) 
Ojeda F, Marañón T, Arroyo J (1996) Postfire regeneration of a Mediterranean heathland in Southern Spain. International Journal of Wildland Fire 6, 191-198. doi:10.1071/WF9960191

Papió C (1994) Ecologia del foc i regeneració en garrigues i pinedes mediterrànies. (Institut d'Estudis Catalans: Barcelona)

Pausas JG (1999) The response of plant functional types to changes in the fire regime in Mediterranean ecosystems. A simulation approach. Journal of Vegetation Science 10, 717-722. doi:10.2307/3237086

Pausas JG (2003) The effect of landscape pattern on Mediterranean vegetation dynamics: a modelling approach using functional types. Journal of Vegetation Science 14, 365-374.

Pausas JG (2004) Changes in fire and climate in the Eastern Iberian Peninsula (Mediterranean Basin). Climatic Change 63, 337-350. doi:10.1023/B:CLIM.0000018508.94901.9C

Pausas JG (2006) Simulating Mediterranean landscape pattern and vegetation dynamics under different fire regimes. Plant Ecology 187, 249-259. doi:10.1007/S11258-006-9138-Z

Pausas JG, Lavorel S (2003) A hierarchical deductive approach to functional types in disturbed ecosystems. Journal of Vegetation Science 14, 409416. doi:10.1658/1100-9233(2003)014[0409:AHDAFF]2.0.CO;2

Pausas JG, Abdel Malak D (2004) Spatial and temporal patterns of fire and climate change in the eastern Iberian Peninsula (Mediterranean Basin). In 'Ecology, Conservation and Management of Mediterranean Climate Ecosystems of the World'. MEDECOS 10th International Conference, Rhodes, Greece. (Eds M Arianoutsou, VP Papanastasis) (Millpress: Rotterdam, The Netherlands)

Pausas JG, Verdú M (2005) Plant persistence traits in fire-prone ecosystems of the Mediterranean basin: a phylogenetic approach. Oikos 109, 196202. doi:10.1111/J.0030-1299.2005.13596.X

Pausas JG, Ramos JI (2006) Landscape Analysis and Simulation Shell (LASS). Environmental Modelling \& Software 21, 629-639. doi:10.1016/J.ENVSOFT.2004.11.009

Pausas JG, Carbó E, Caturla RN, Gil JM, Vallejo VR (1999) Post-fire regeneration patterns in the Eastern Iberian Peninsula. Acta Oecologica 20, 499-508. doi:10.1016/S1146-609X(00)86617-5

Pausas JG, Bradstock RA, Keith DA, Keeley JE, GCTE Fire Network (2004) Plant functional traits in relation to fire in crown-fire ecosystems. Ecology 85, 1085-1100. doi:10.1890/02-4094

Pérez B, Moreno JM (1998) Fire-type and forestry management effects on the early postfire vegetation dynamics of a Pinus pinaster woodland. Plant Ecology 134, 27-41. doi:10.1023/A:1009733818670

Piñol J, Beven K, Viegas DX (2005) Modelling the effect of fire-exclusion and prescribed fire on wildfire size in Mediterranean ecosystems. Ecological Modelling 183, 397-409. doi:10.1016/J.ECOLMODEL.2004. 09.001

Piñol J, Terradas J, Lloret F (1998) Climate warming, wildfire hazard, and wildfire occurrence in coastal eastern Spain. Climatic Change 38, 345357. doi:10.1023/A:1005316632105

Rodrigo A, Retana J, Picó FX (2004) Direct regeneration is not the only response of Mediterranean forests to large fires. Ecology 85, 716-729. doi:10.1890/02-0492
Riera J, Castell C (1997) Efectes dels incendis forestals recurrents sobre la distribució de dues espècies del Parc Natural del Garraf: el pi blanc (Pinus halepensis) i la savina (Juniperus phoenicea). Butlletí de la Institució Catalana d'Historia Natural 65, 105-116.

Romme WH (1982) Fire and landscape diversity in subalpine forests of Yellowstone National Park. Ecological Monographs 52, 199-221. doi:10.2307/1942611

SchoennagelT, Waller DM, Turner MG, Romme WH(2004) The effect of fire interval on post-fire understorey communities in Yellowstone National Park. Journal of Vegetation Science 15, 797-806. doi:10.1658/11009233(2004)015[0797:TEOFIO]2.0.CO;2

Syphard AD, Franklin J, Keeley JE (2006) Simulating the effects of frequent fire on southern California coastal shrublands. Ecological Applications 16, 1744-1756. doi:10.1890/1051-0761(2006)016[1744:STEOFF] 2.0.CO;2

Turner MG (1989) Landscape ecology: the effect of pattern on process. Annual Review of Ecology and Systematics 20, 171-197. doi:10.1146/ ANNUREV.ES.20.110189.001131

Turner MG, Hargrove WW, Gardner HH, Romme WH (1994) Effect of fire on landscape heterogeneity in Yellowstone National Park, Wyoming. Journal of Vegetation Science 5, 731-742. doi:10.2307/3235886

Turner MG, Romme WH (1994) Landscape dynamics in crown fire ecosystems. Landscape Ecology 9, 59-77. doi:10.1007/BF00135079

van Wilgen BW, Bond WJ, Richardson DM (1992) Ecosystem Management. In 'The Ecology of fynbos. Nutrients, fire and diversity'. (Ed. R Cowling) pp. 345-371. (Oxford University Press: Cape Town)

Weir JMH, Johnson EA (2000) Fire frequency and the spatial age mosaic of the mixed-wood boreal forest in Western Canada. Ecological Applications 10, 1162-1177.

Zammit C (1988) Dynamics of resprouting in the lignotuberous shrub Banksia oblongifolia. Australian Journal of Ecology 13, 311-320. doi:10.1111/J.1442-9993.1988.TB00979.X

Zedler PH (1995a) Fire frequency in southern California shrublands: biological effects and management options. In 'Brushfires in California: ecology and resource management'. (Eds JE Keeley, T Scott) pp. 101-112. (International Association of Wildland Fire: Fairfield, WA, USA)

Zedler PH (1995b) Plant life history and dynamic specialization in the chaparral/coastal sage shrub flora in southern California. In 'Ecology and biogeography of Mediterranean ecosystems in Chile, California and Australia'. (Eds MTK Arroyo, PH Zedler, MD Fox) pp. 89-115. (Springer-Verlag: New York)

Zedler PH, Gautier CR, McMaster GS (1983) Vegetation change in response to extreme events: the effect of a short interval between fires in California chaparral and coastal sage scrub. Ecology 64, 809-818. doi: $10.2307 / 1937204$

Manuscript received 13 July 2006, accepted 28 February 2007 